\title{
Pollution reduction and biodegradability index improvement of tannery effluents
}

\author{
${ }^{1 *}$ M. A. Aboulhassan; ${ }^{1}$ S. Souabi; ${ }^{2}$ A. Yaacoubi \\ ${ }^{1}$ Laboratoire de Génie de l'Eau et de l'Environnement, Faculté des Sciences et Techniques, \\ BP 146 Mohammedia, Maroc \\ ${ }^{2}$ Laboratoire de Chimie Organique Appliquée, Equipe Environnement et Méthodologie, Faculté des Sciences Semlalia, \\ BP 2390, Marrakech, Maroc \\ Received 29 May 2007; revised 20 June 2007; accepted 14 October 2007; $\quad$ available online 26 December 2007
}

\begin{abstract}
Al}_{2}\left(\mathrm{SO}_{4}\right)_{3}, 18 \mathrm{H}_{2} \mathrm{O}, \mathrm{FeCl}_{3}$ and $\mathrm{Ca}(\mathrm{OH})_{2}$ were used for the treatment of tannery wastewaters. The influences of $\mathrm{pH}$ and coagulant dosages were studied. Conditions were optimised according to the pollutant removal efficiencies, the volume of decanted sludge and the biodegradability index improvement. The results indicate that 67$71 \%$ of total COD, $76-92 \%$ of color and $79-97 \%$ of $\mathrm{Cr}$ can be removed using the optimum coagulant dosages at the optimum pH range. $\mathrm{Al}_{2}\left(\mathrm{SO}_{4}\right)_{3}, 18 \mathrm{H}_{2} \mathrm{O}$ and $\mathrm{Ca}(\mathrm{OH})_{2}$ produced better results than $\mathrm{FeCl}_{3}$ in terms of $\mathrm{COD}$, color and $\mathrm{Cr}$ removal as well as in terms of biodegradability improvement. Moreover, $\mathrm{Al}_{2}\left(\mathrm{SO}_{4}\right)_{3}, 18 \mathrm{H}_{2} \mathrm{O}$ and $\mathrm{FeCl}_{3}$ produced the least amount of sludges for a given amounts of COD, color and $\mathrm{Cr}$ removed in comparison with $\mathrm{Ca}(\mathrm{OH})_{2}$. $\mathrm{Al}_{2}\left(\mathrm{SO}_{4}\right)_{3}$, $18 \mathrm{H}_{2} \mathrm{O}$ seems to be suitable for yielding high pollutant removals and corresponding low volumes of decanted sludges in addition to improving wastewaters biodegradability index.
\end{abstract}

Key words: Tannery wastewater, coagulation, sludges production, biodegradability index

\section{INTRODUCTION}

The tanning of hides and skins to convert them into leather has been an important activity since antiquity. Approximately 30-40 $\mathrm{m}^{3}$ of water are used per $\mathrm{t}$ of hide processed (Suthanthararajan, et al., 2004). With the present annual global processing capacity of $9 \times 10^{9}$ Kg hides and skins, it is estimated that $30-40 \times 10^{10}$ litres of liquid effluent is generated (Thanikaivelan, et al., 2004). This gives rise to two major problems for the leather industry: the availability of good quality water and the treatment of such large quantities of effluent. The tannery wastewater is a mixture of biogenic matter of hides and a large variety of organic and inorganic chemicals. Wastewater from tanneries usually contains high levels of salinity, organic loading, inorganic matter, color matter, dissolved and suspended solids, ammonia, organic nitrogen and specific pollutants (sulphide, chromium and other toxic metal salt residues), (Ros and Gantar, 1998). The potential environmental impact of the chemicals used in tannery operations has been widely acknowledged. Cr containing effluents find their way in the environment at disposal sites where $\mathrm{Cr}$ undergoes oxidation reactions and forms $\mathrm{Cr}(\mathrm{Vl})$

ه *Corresponding Author Email: a.aboulhassan@gmail.com Tel.: 212675178 17Fax: 21223315353
(Bartlett and James, 1979). As Cr (VI) is readily soluble in water, it leaches down in the soil profile and could contaminate groundwater (Sumathi, et al., 2005). Furthermore, the discharge of such colored wastewater into the environment is not only aesthetically displeasing, but also impedes light penetration, damages the quality of the receiving streams and may be toxic to the treatment processes, to food chain organisms and to aquatic life (Mahdavi Talarposhti, et al., 2001). Thus, leather tanning generates many complex and high loaded effluents that require treatment before being discharged into the environment. Various physico-chemical techniques have been studied for their applicability to the treatment of tannery wastewater (Orhon, et al., 1998; Amokrane, et al., 1997). Among these are coagulation, flocculation, ozonation, reverse osmosis, ion exchange and adsorption (Arvanitoyamis, et al., 1989). Coagulation flocculation is one of the important treatments given to the industrial effluent before discharging them into receiving waters to remove toxic waste. Many researchers have investigated the coagulation of tannery wastewater. However, few of them attempted to fully investigate the optimisation of coagulation for 
color reduction or in conjunction with subsequent biological treatability of coagulated tannery wastewater. Indeed, the coagulation process is not always perfect and may result in treated wastewaters of which the characteristics did not meet the proposed effluent standards. Consequently, a further treatment is often necessary. This paper describes experimental studies that were conducted on tannery wastewaters in order to evaluate coagulation precipitation process efficiency for the treatment of tannery effluents, especially in terms of organic matter, color and $\mathrm{Cr}$ removal as well as sludges production. In addition, the effect of coagulation flocculation process on biodegradability index improvement is also discussed.

\section{MATERIALS AND METHODS}

The samples were collected from a tannery located at Mohammedia city in Morocco. Different wastewater streams are generated at different times and as a result, the effluent characteristics in the main drain vary significantly (Table 1). Since no equalisation tank is provided, the hourly samples collected over one production cycle $(8 \mathrm{~h}$.) are thoroughly mixed in a drum to make a representative sample. $\mathrm{Al}_{2}\left(\mathrm{SO}_{4}\right)_{3}, 18 \mathrm{H}_{2} \mathrm{O}, \mathrm{FeCl}_{3}$ and $\mathrm{Ca}(\mathrm{OH})_{2}$ are used as chemical coagulants.

Table 1: Characterisation of the main drain tannery wastewaters*

\begin{tabular}{lllc}
\hline Parameters & Min. & Max. & Average \\
\hline $\mathrm{pH}$ & 5.6 & 6.6 & 6.2 \\
Conductivity (ms/cm) & 9.5 & 41.2 & 35.6 \\
Turbidity (FTU) & 177 & 383 & 296 \\
SM (mg/L) & 550 & 1686 & 1152 \\
Sulphate (mg/L) & 1060 & 6801 & 4662 \\
Chloride (mg/L) & 1065 & 2485 & 1860 \\
Total phosphorus (mg/L) & 7 & 12 & 10 \\
TKN (mg/L) & 168 & 284 & 252 \\
BOD (mg/L) & 102 & 492 & 371 \\
COD (mg/L) & 1056 & 4723 & 3226 \\
Chromium (mg/L) & 10 & 130 & 65 \\
H ${ }_{2}$ S (mg/L) & 65 & 160 & 118 \\
\hline *Number of samples $=8$ & & &
\end{tabular}

Jar test experiments were conducted under controlled laboratory conditions using a standard jar test apparatus. Four equal-volume polyethylene beakers were used to examine the four different dosages of coagulant or initial $\mathrm{pH}$ values in each run. Sample bottles were thoroughly shaken for the resuspension of possibly settling solids and the appropriate volume of sample was transferred to the corresponding jar test beakers. The experimental process consists of three subsequent stages: Initial rapid mixing stage at 160 rpm took place for $5 \mathrm{~min}$. and it was followed by a slow mixing stage for $20 \mathrm{~min}$. at $30 \mathrm{rpm}$; the final settling step lasts for another $1 \mathrm{~h}$. To evaluate the efficiency of coagulants on tannery wastewater treatment, the following parameters were determined: turbidity, chemical oxygen demand (COD), biological oxygen demand (BOD), color, chromium content and the amount of the sludges produced.

Color measurement: Prior to color measurement, the sample was filtered through a $0.45 \mu \mathrm{m}$ Millipore membrane filter to prevent turbidity. Color measurements were carried out with a spectrophotometer. Since the wastewater contains different kinds of dyes (depending on the production), the traditional method of applying the maximum absorbance was not utilized. Color is determined using a UV-visible spectrophotometer (Model 7800 UV/VIS) by measuring the absorbance at three wavelengths $(436,525$, and 620 $\mathrm{nm})$ and taking the sum of these three measurements (Olthof and Eckenfelder, 1976; Aysegül and Enis, 2002). Chromium: the concentration of chromium in the liquid phase was determined by graphite furnace atomic absorption spectrometry (SCHIMADZU AA-6800).

Turbidity: the turbidity was determined by turbidity meter (HI 93703 Microprocessor turbidity meter). COD, BOD and other physicochemical parameters analyzed were determined according to the standard methods (AFNOR, 1999).

Volume of sludges: At the end of the slow mixing stage, the beaker contents were transferred into Imhoff cones and allowed to settle for one h. The volume of the settled sludges in the cone was recorded according to the volumetric method (Eaton, et al., 1995).

\section{RESULTS AND DISCUSSION}

The effect of $\mathrm{pH}$ on turbidity removal from jar tests for coagulation of tannery wastewater is shown in Fig. 1. Figs. 2, 3 and 4 show the effect of coagulant addition on the reduction of COD, color and chromium at the optimum coagulation $\mathrm{pH}$ for each coagulant $(\mathrm{pH} 5$ for $\mathrm{FeCl}_{3}$ and $\mathrm{pH} 8$ in the case of $\left.\mathrm{Al}_{2}\left(\mathrm{SO}_{4}\right)_{3}, 18 \mathrm{H}_{2} \mathrm{O}\right)$. The ratios between the amount of sludges produced and the amount of COD, color and chromium removed are presented in Fig. 5. Fig. 6 shows the biodegradability index of wastewaters for the optimal doses of coagulants. Finally, the optimal coagulant doses and also the cost of the different products used are reported in Table 2. The solution $\mathrm{pH}$ is an important factor in the coagulation process (Duan and Gregory, 2003). The 
use of coagulant at its optimum $\mathrm{pH}$ displays maximum pollutant removal. In addition, with such optimum $\mathrm{pH}$ conditions, the soluble residual aluminium and iron content in the wastewater will be lower than $0.5 \mathrm{mg} / \mathrm{L}$ and $2 \mathrm{mg} / \mathrm{L}$, respectively (Amokrane, et al., 1997; Letterman and Driscoll, 1988). It can be seen that turbidity removal is most effective at a $\mathrm{pH}$ range between 7 and 8 for $\mathrm{Al}_{2}\left(\mathrm{SO}_{4}\right)_{3}, 18 \mathrm{H}_{2} \mathrm{O}$ and between 5 and 7 for $\mathrm{FeCl}_{3}$ (Fig. 1). In case of both aluminium and iron, the hydroxide is of very low solubility and an amorphous precipitate $\mathrm{Me}(\mathrm{OH})_{3}$ (Me: Metal) can form at intermediate $\mathrm{pH}$ values. This is of enormous practical significance in the reaction of these materials as coagulants. The total amount of soluble species in equilibrium with the amorphous solid is effectively the solubility of the metal and it can be seen that in each case, there is a minimum solubility at a certain $\mathrm{pH}$ value. The $\mathrm{pH}$ range of 6.5-7.5 for $\mathrm{Al}_{2}\left(\mathrm{SO}_{4}\right)_{3}, 18 \mathrm{H}_{2} \mathrm{O}$ and 6.58.5 for $\mathrm{FeCl}_{3}$ were determined as the optimal $\mathrm{pH}$ ranges of the removal of COD from tannery wastewaters (Song et al., 2004). On the basis of an initial COD concentration of $3442 \mathrm{mg} / \mathrm{L}$, the addition of $100 \mathrm{mg} / \mathrm{L}$ of coagulant decreases COD by 2, 18 and $34 \%$ using $\mathrm{Al}_{2}\left(\mathrm{SO}_{4}\right)_{3}$, $18 \mathrm{H}_{2} \mathrm{O}, \mathrm{Ca}(\mathrm{OH})_{2}$ and $\mathrm{FeCl}_{3}$, respectively (Fig. 2). The results indicate that a maximum COD removal of $71 \%$ can be achieved through using both $\mathrm{Al}_{2}\left(\mathrm{SO}_{4}\right)_{3}, 18 \mathrm{H}_{2} \mathrm{O}$ and $\mathrm{Ca}(\mathrm{OH})_{2}$ at $600 \mathrm{mg} / \mathrm{L}$ and $1000 \mathrm{mg} / \mathrm{L}$, respectively.

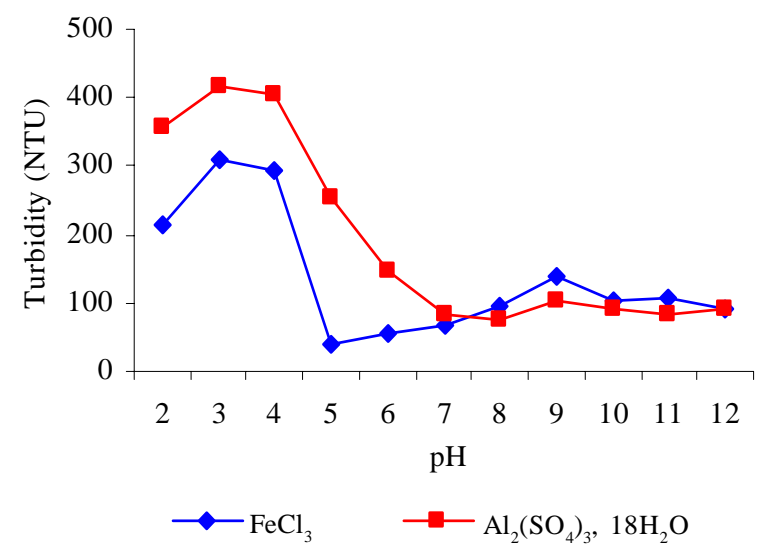

Fig. 1: Effect of coagulation $\mathrm{pH}$ on turbidity removal
However, the maximum percentage of COD removal that $\mathrm{FeCl}_{3}$ could remove is $67 \%$ at the coagulant dose of 400 $\mathrm{mg} / \mathrm{L}$. Residual COD concentration is of $996 \mathrm{mg} / \mathrm{L}$ for both $\mathrm{Al}_{2}\left(\mathrm{SO}_{4}\right)_{3}, 18 \mathrm{H}_{2} \mathrm{O}$ and $\mathrm{Ca}(\mathrm{OH})_{2}$ and of $1122 \mathrm{mg} / \mathrm{L}$ for $\mathrm{FeCl}_{3}$. This may be explained by the solubility of a part of COD. Consequently, it cannot be removed by decantation. Color is considered in this work as it may affect the feasibility of a subsequent biological treatment. Dyes present in wastewaters cause significant problems at treatment plant, since those compounds are hard to degrade through biological means. The effect of coagulation flocculation on color removal shows that this process is effective on color reduction; the maximum percentage of color removed are $92 \%, 81 \%$ and $77 \%$ using $\mathrm{Ca}(\mathrm{OH})_{2}, \mathrm{Al}_{2}\left(\mathrm{SO}_{4}\right)_{3}, 18 \mathrm{H}_{2} \mathrm{O}$ and $\mathrm{FeCl}_{3}$, respectively (Fig. 3). Substances producing color consist either of colloidal metallic hydroxides (e.g., iron hydroxides) or of organic compounds (e.g., dyestuff), which have a much smaller particle size. These substances can be removed by coagulation, which serves to agglomerate the very small particles into sizes that can be settled or can be removed by filters or absorption. Coagulation using $\mathrm{FeCl}_{3}$ appeared to be less effective than $\mathrm{Al}_{2}\left(\mathrm{SO}_{4}\right)_{3}, 18 \mathrm{H}_{2} \mathrm{O}$ and $\mathrm{Ca}(\mathrm{OH})_{2}$ in removing color. This may be explained assuming the fact that coagulants containing Fe produce color problems in effluents including sulphide or vegetable

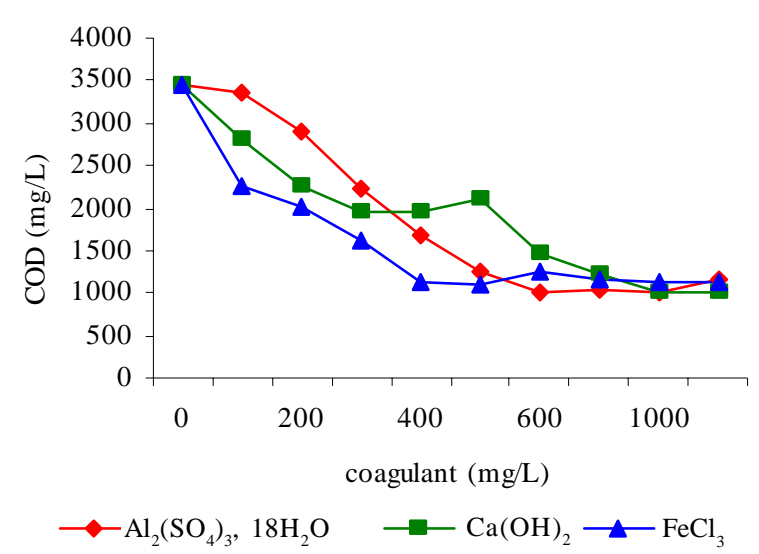

Fig. 2: Effect of coagulant doses on COD removal

Table 2: Percent color, COD and Cr removals, sludges production and chemical cost for coagulation flocculation process using various coagulants

\begin{tabular}{|c|c|c|c|c|c|c|}
\hline Coagulants & $\begin{array}{c}\text { Doses } \\
(\mathrm{mg} / \mathrm{L})\end{array}$ & $\begin{array}{c}\text { COD removal } \\
(\%)\end{array}$ & $\begin{array}{c}\text { Color removal } \\
(\%)\end{array}$ & $\begin{array}{c}\text { Cr removal } \\
(\%)\end{array}$ & $\begin{array}{l}\text { Sludge } \\
\text { (mg/L) }\end{array}$ & Cost $\left(€ / \mathrm{m}^{3}\right)$ \\
\hline $\mathrm{FeCl}_{3}$ & 400 & 67 & 76 & 79 & 88 & 0.30 \\
\hline $\mathrm{Al}_{2}(\mathrm{SO} 4)_{3}, 18 \mathrm{H}_{2} \mathrm{O}$ & 600 & 71 & 80 & 89 & 103 & 0.88 \\
\hline $\mathrm{Ca}(\mathrm{OH})_{2}$ & 1000 & 71 & 92 & 97 & 140 & 0.32 \\
\hline
\end{tabular}




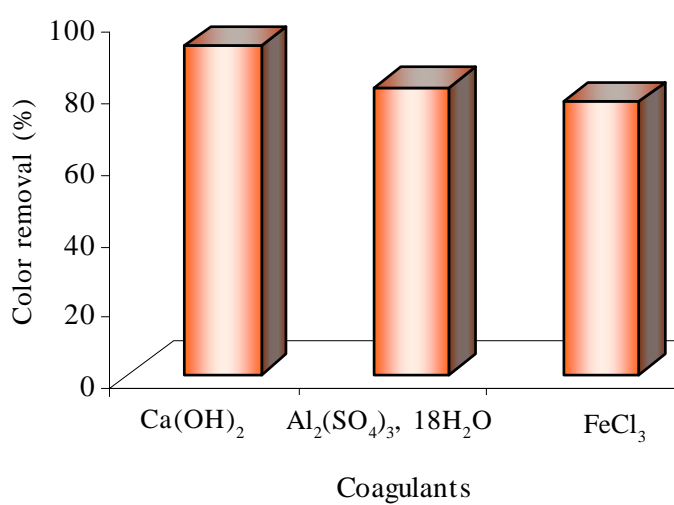

Fig. 3: Color removal using different coagulants

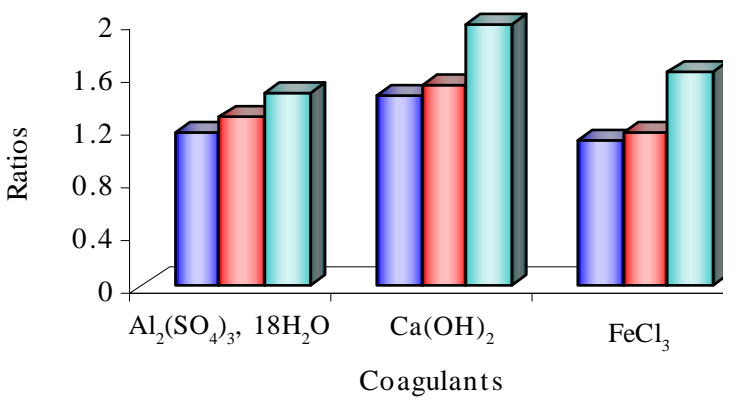

$\square$ sludges / chromium $\square$ sludges / color $\square$ sludges / COD

Fig. 5: Ratios between the volumes of sludges produced $(\mathrm{mL})$ and the COD, $\mathrm{Cr}$ and color reduction (\%) for different coagulants at optimal doses

tannins (Bousher, et al., 1997). Table 1 indicates that the tannery wastewaters contain appreciable amounts of sulphide. Moreover, the company, in addition to chrome leather production, uses also the vegetable tanning process. For an initial wastewater chromium concentration of $47 \mathrm{mg} / \mathrm{L}$, the chromium removal reaches 97,89 and $79 \%$ using $\mathrm{Ca}(\mathrm{OH})_{2}, \mathrm{Al}_{2}\left(\mathrm{SO}_{4}\right)_{3}, 18 \mathrm{H}_{2} \mathrm{O}$ and $\mathrm{FeCl}_{3}$, respectively (Fig. 4). Ros and Gantar, (1998) investigated the effect of $\mathrm{pH}$ on chromium removal and concluded that coagulation should be operated at an alkaline range to achieve maximum chromium removal. However, the optimal coagulation $\mathrm{pH}$ (Fig. 1) is acidic in case of $\mathrm{FeCl}_{3}$ and slightly alkaline for $\mathrm{Al}_{2}\left(\mathrm{SO}_{4}\right)_{3}$, $18 \mathrm{H}_{2} \mathrm{O}$. In addition, the acidic characters of $\mathrm{Fe}^{3+}$ and $\mathrm{A}^{3+}$ (Lewis acids) decreased the $\mathrm{pH}$ of the medium. Then, the percentage of chromium removed using $\mathrm{FeCl}_{3}$ (only 79\%) can be explained by the acidic $\mathrm{pH}$ of the medium. On the contrary, the addition of $\mathrm{Ca}(\mathrm{OH})_{2}$ increases the $\mathrm{pH}$ of the wastewaters $(\mathrm{pH}$ 9.1) and allows

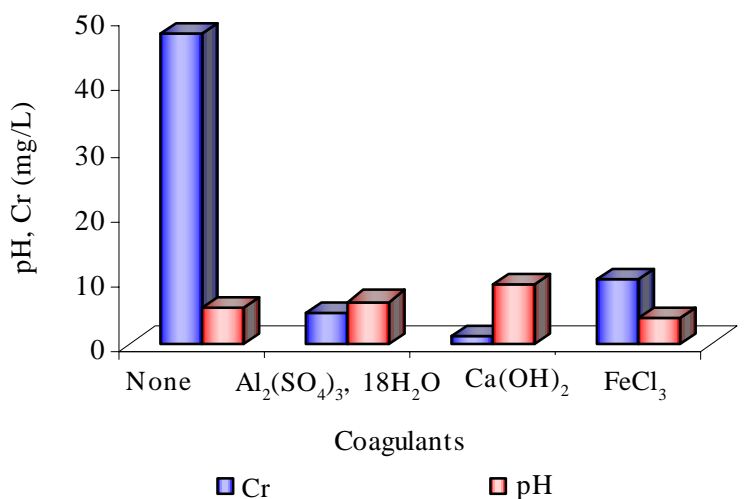

Fig. 4: Effect of coagulants at optimal doses on $\mathrm{pH}$ and $\mathrm{Cr}$ removal

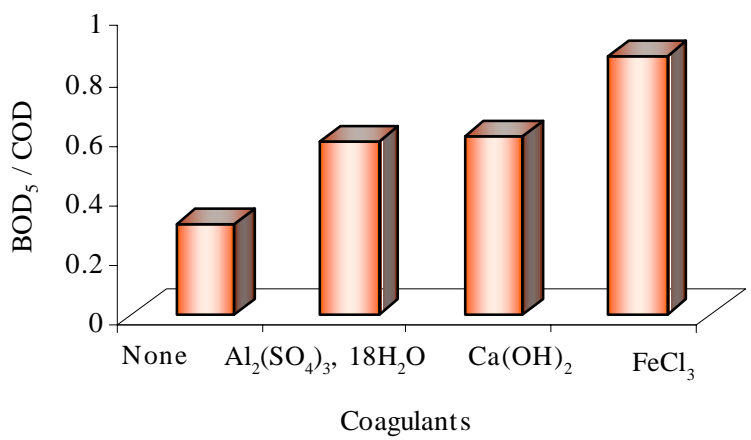

Fig. 6: Biodegradability index of wastewaters at optimal doses of coagulants

an effective chromium reduction. This may be explained by the association of coagulant and $\mathrm{pH}$ effects. The results indicate that the residual chromium concentrations using $\mathrm{FeCl}_{3}, \mathrm{Al}_{2}\left(\mathrm{SO}_{4}\right)_{3}, 18 \mathrm{H}_{2} \mathrm{O}$ and $\mathrm{Ca}(\mathrm{OH})_{2}$ are $9.7,4.8$ and $1.2 \mathrm{mg} / \mathrm{L}$, respectively. When physico-chemical treatment is applied to waste water by coagulation-flocculation, a large amount of sludges is generated. Sludges production may affect the economic feasibility of the proposed method. Therefore, when choosing a coagulant, one aspect to be considered is how much of sludges will be produced (James and O'melia, 1982). In order to compare the results obtained using such coagulants, the ratio between the amount of sludges produced and the amount of COD, color and chromium removed has been estimated (Aboulhassan, et al., 2005; Aguilar, et al., 2002). Fig. 5 shows that $\mathrm{Al}_{2}\left(\mathrm{SO}_{4}\right)_{3}, 18 \mathrm{H}_{2} \mathrm{O}$ and $\mathrm{FeCl}_{3}$ produced the least amount of sludges for a given amount of COD, color and chromium removed in 
comparison with $\mathrm{Ca}(\mathrm{OH})_{2}$. Indeed, $\mathrm{Ca}(\mathrm{OH})_{2}$ is very effective in the removal of COD, color and chromium. However, it produces more sludges. Considering the results obtained, if a small volume of sludges is to be treated, the $\mathrm{Al}_{2}\left(\mathrm{SO}_{4}\right)_{3}, 18 \mathrm{H}_{2} \mathrm{O}$ and $\mathrm{FeCl}_{3}$ are suitable. However, $\mathrm{Al}_{2}\left(\mathrm{SO}_{4}\right)_{3}, 18 \mathrm{H}_{2} \mathrm{O}$ is more effective in the removal of COD, color and chromium than $\mathrm{FeCl}_{3}$. Consequently, $\mathrm{Al}_{2}\left(\mathrm{SO}_{4}\right)_{3}, 18 \mathrm{H}_{2} \mathrm{O}$ is suitable. A significant proportion of the soluble matter in the effluent (e.g. soluble COD) is not removed by the physico-chemical treatment. In order to achieve a higher quality of treated water, further treatments will be needed prior to discharge. It is likely that a biological treatment, as an inexpensive process, would need to be incorporated for maximum treatment. Many authors use the $\mathrm{BOD}_{5} / \mathrm{COD}$ ratio as biodegradability index. Wastewater can be considered readily biodegradable if it has a ratio value between 0.4 and 0.8 (Metcalf and Eddy, 1985; Al-Momani, et al., 2002). As shown in Fig. 6, $\mathrm{Al}_{2}\left(\mathrm{SO}_{4}\right)_{3}, 18 \mathrm{H}_{2} \mathrm{O}$ and $\mathrm{Ca}(\mathrm{OH})_{2}$ lead to noticeable improvement in the biodegradability index. However, the $\mathrm{BOD}_{5} / \mathrm{COD}$ ratio of treated wastewaters exceeds 0.8 using $\mathrm{FeCl}_{3}$. This may be explained by the fact that treated wastewaters using $\mathrm{FeCl}_{3}$ are $\mathrm{Cr}$ and color riches, compared to these obtained using $\mathrm{Al}_{2}\left(\mathrm{SO}_{4}\right)_{3}, 18 \mathrm{H}_{2} \mathrm{O}$ and $\mathrm{Ca}(\mathrm{OH})_{2}$. These pollutants were known to be toxic to biological treatment processes (Mahdavi Talarposhti, et al., 2001; Florence and Bately, 1980; Sumathi, et al., 2005). In order to reduce the soluble pollution, treated wastewaters using $\mathrm{Al}_{2}\left(\mathrm{SO}_{4}\right)_{3}, 18 \mathrm{H}_{2} \mathrm{O}$ or $\mathrm{Ca}(\mathrm{OH})_{2}$ can be subject to a further treatment using biological process. These coagulants reduce $\mathrm{Cr}$ wastewaters content and enhance the biodegradability index more than $\mathrm{FeCl}_{3}$. The proper determination of coagulant and flocculant types and dosages will not only improve the resulting water characteristics, but also decreases the cost of treatment. Table 2 shows the optimal coagulant doses and also the cost of the different used products. The use of $\mathrm{Al}_{2}\left(\mathrm{SO}_{4}\right)_{3}, 18 \mathrm{H}_{2} \mathrm{O}$ affects the cost of treatment. However, it is more efficient than $\mathrm{Fe}^{3+}, \mathrm{Cl}^{-}$and $\mathrm{Pb}$ to a noticeable reduction of the decanted sludges compared with $\mathrm{Ca}(\mathrm{OH})_{2}$. $\mathrm{Al}_{2}\left(\mathrm{SO}_{4}\right)_{3}, 18 \mathrm{H}_{2} \mathrm{O}$ seems to be suitable in the treatment of tannery wastewaters for yielding a high pollutant removal and a corresponding low volume of decanted sludge as well as biodegradability index improvement for the subsequent biological treatment.

\section{REFERENCES}

Aboulhassan, M. A.; Souabi, S.; Yaacoubi, A.; Baudu, M., (2005). Treatment of textile wastewater using a natural flocculant. Environ. Tech., 26, 705-711.

AFNOR (1999). Techniques, la qualité de l'eau, Association Française de Normalisation.

Aguilar, M. I.; Saez, J.; Lioréns, M.; Soler, A.; Ortuno, J. F., (2002). Nutrient removal and sludges production in the coagulation-floculation process. Water Res. 36, 2910-2919.

Al-Momani, F.; Touraud, E.; Degorce Dumas, J. R.; Roussy, J.; Thomas, O., (2002). Biodegradability enhancement of textile dyes and textile wastewater by UV photolysis. J. Photoch. Photobio. A, 153, 191-197.

Amokrane, A.; Comel, C.; Veron, J., (1997). Landfill leachates pre-treatment by coagulation-flocculation. Water Res. 31, 2775-2782.

Arvanitoyamis, I.; Eleftheriadis, I.; Tsatsaroni, E., (1989). Influence of $\mathrm{pH}$ on adsorption of dye-containing effluents with different bentonites. Chemosphere. 18, 1707-1711.

Aysegül, P.; Enis, T., (2002). Color removal from cotton textile industry wastewater in an activated sludges system with various additives. Water Res. 36, 2920-2925.

Bartlett, R. J.; James, D., (1979). Behavior of chromium in soils: III oxidation. J. Environ. Qual., 8, 31-35.

Bousher, A.; Shen, X.; Edyvean, R. G. J., (1997). Removal of colored organic mater by adsorption onto lowcost waste materials. Water Res., 31, 2084-2092.

Duan, J.; Gregory, J., (2003). Coagulation by hydrolysing metal salts. Adv. Colloid Interface, 100, 475-502.

Eaton, A. D.; Clescen, L. S.; Greenberg, A. E., (1995). Stetard methods for the examination of water and wastewater. APHA.19 ${ }^{\text {th. }}$ Ed. In: Editted by Washington: APM, setts. Report \# 331.

Florence, T. M.; Bately, G. E., (1980). Chemical speciation in natural waters. CRC Cr. Rev. Anal. Chem., 9, 219-296.

James, C. R.; O’melia, C. R., (1982). Considering sludges production in the selection of coagulants. J. Am. Water Works Ass., 74, 148-151.

Letterman, R. D.; Driscoll, C. T., (1988). Survey of residual aluminum in filtered water. J. Am. Water Works Ass., 80, 154-158.

Mahdavi Talarposhti, A.; Donnelly, T.; Andersonm, G. K., (2001). Color removal from a simulated dye wastewater using a two-phase anaerobic packed bed reactor, Water Res., 35, 425-432.

Metcalf and Eddy, (1985). Wastewater Engineering: Treatment,

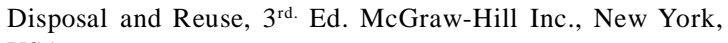
USA.

Olthof, M.; Eckenfelder, W. W., (1976). Coagulation of textile wastewater. Text. Chem. Color, 8, 18-22.

Orhon, D.; Sgzen, S.; Ubay Cokgsr, E.; Ates, E., (1998). The effect of chemical settling on the kinetics and design of activated sludges for tannery wastewater. IAWQ $19^{\text {th. }}$ Biennial International Conference.

Ros, M.; Gantar, A., (1998). Possibilities of reduction of recipient loading of tannery wastewater in Slovenia. Water Sci. Tech., 37, 145-152.

Song, Z.; Williams, C. J.; Edyvean, R. G. J., (2004). Treatment of tannery wastewater by chemical coagulation. Desalination, 164, 249-259. 
Sumathi, K. M. S.; Mahimairaja, S.; Naidu, R., (2005). Use of low-cost biological wastes and vermiculite for removal of Cr from tannery effluent. Bioresource Tech., 96, 309316.

Suthanthararajan, R.; Ravindranath, E.; Chitra, K.; Umamaheswari, B.; Ramesh, T.; Rajamani, S., (2004).
Membrane application for recovery and reuse of water from treated tannery wastewater. Desalination, 164, 151-156.

Thanikaivelan, P.; Jonnalagadda, R. R.; Balachetran, U. N.; Ramasami, T., (2004). Progress and recent trends in biotechnological methods for leather processing. Trends Biotech. 22, 181-188.

\section{AUTHOR (S) BIOSKETCHES}

Aboulhassan, M. A., P.hD., Faculty of Sciences and Technologies, Mohammedia, Morocco.

Email: a.aboulhassan@gmail.com

Souabi, S., P.hD., Professor, Faculty of Sciences and Technologies, Mohammedia, Morocco.

Email: s_souabi@yahoo.fr

Yaacoubi, A., P.hD., Professor, Faculty of Sciences Semlalia, Marrakech, Morocco.

Email:abdelghaniyaacoubi@yahoo.fr

This article should be referenced as follows:
Aboulhassan, M. A.; Souabi, S.; Yaacoubi, A., (2008). Pollution reduction and biodegradability index improvement
of tannery effluents. Int. J. Environ. Sci. Tech., 5(1), 11-16.

